\title{
56. A case study on EFL teachers' views on material adaptation for teaching pragmatics
}

\author{
Çiğdem KARATEPE ${ }^{1}$
}

Mustafa CIVELEK²

\begin{abstract}
APA: Karatepe, Ç.; Civelek, M. (2021). A case study on EFL teachers' views on material adaptation for teaching pragmatics. RumeliDE Dil ve Edebiyat Araşturmaları Dergisi, (23), 894-910. DOI: 10.29000/rumelide.953259.
\end{abstract}

\begin{abstract}
The teaching of pragmatic features in the field of ELT has received more attention recently. Many studies indicated that English textbooks fail to represent the features of pragmatics. Yet, textbooks are a valuable source of information for students, so it is vital for teachers to be able to enrich the textbook activities for teaching pragmatics. However, to what extent teachers can achieve this has not been investigated yet. Moreover, no studies have been found investigating the views of EFL teachers on the teaching materials for pragmatics instruction. To fill in this gap, a dialogue activity aiming to teach requests was modified based on the relevant literature. The modified activity was presented to the attention of 100 Turkish EFL teachers. Then, the views of EFL teachers on the modified activity were investigated through a questionnaire and semi-structured interviews. The study also aimed to question if teachers were willing to adapt textbook activities for more effective pragmatics instruction. The results indicated that teachers found the modifications useful for pragmatics instruction. Furthermore, no statistically significant difference was found between those who had taken a course on pragmatics during their teacher training and the ones who had not. It was found that teachers regarded material adaptation for the instruction of pragmatics as a must. Even so, they admitted that none of them had made such adaptations as they thought they were not equipped with a satisfying level of knowledge on pragmatics.
\end{abstract}

Keywords: Pragmatics instruction, ELT material adaptation, speech acts, requests

\section{İngilizce öğretmenlerinin edimbilim öğretimi için materyal uyarlaması konusundaki görüşleri üzerine örnek bir inceleme}

\author{
$\ddot{\mathbf{O z}}$
}

İngiliz dili eğitimi alanında son zamanlarda edimbilimsel dil öğelerinin öğretimi daha fazla ilgi görmeye başlamıştır. Alandaki araştırmalar, İngilizce ders kitaplarının edimbilimsel öğeleri sunma konusunda yetersiz kaldığını göstermiştir. Ders kitaplarının öğrenciler için önemli bir bilgi kaynağı olması nedeniyle, öğretmenlerin ders kitaplarındaki edimbilim aktivitelerini zenginleştirebilmeleri önemlidir. Ancak, öğretmenlerin bunu ne ölçüde başarabileceği henüz araştırılmamıştır. İlgili alanyazın incelendiğinde öğretmenlerin edimbilim öğretim materyalleri hakkındaki görüşlerini inceleyen bir çalışmaya rastlanmamıştır. Bu boşluğu doldurmak için, ilk olarak amacı ricaları öğretmek olan bir ders kitabı aktivitesi alanyazın taranarak zenginleştirilmiştir. Sonra bu aktivite

Dr. Öğr. Üyesi, Bursa Uludağ Üniversitesi, Eğitim Fakültesi, Yabancı Diller Eğitimi Bölümü, İngiliz Dili Eğitimi ABD (Bursa, Türkiye), ozlem1@uludag.edu.tr, ORCID ID: 00oo-0002-2902-6656 [Araştırma makalesi, Makale kayıt tarihi: 1.03.2021-kabul tarihi: 20.06.2021; DOI: 10.29000/rumelide.953259]

Yüksek Lisans Öğrencisi, Bursa Uludağ Üniversitesi, Eğitim Bilimleri Enstitüsü, İngiliz Dili Eğitimi Programı (Bursa, Türkiye), mustafacivelek179@gmail.com, ORCID ID: 0000-0002-4304-4252

\section{Adres $\mid$ Address}

RumeliDE Dil ve Edebiyat Araşttrmaları Dergisi Osmanağa Mahallesi, Mürver Ciçç̆i Sokak, No:14/8 Kadıköy - İSTANBUL / TÜRKIYE 34714 e-posta: editor@rumelide.com

RumeliDE Journal of Language and Literature Studies Osmanağa Mahallesi, Mürver Çiçeği Sokak, No:14/8

Kadıköy - ISTANBUL / TURKEY 34714

e-mail: editor@rumelide.com,

tel: +90 505 7958124, +90 216773 o 616 phone: +90 505 7958124, +90 2167730616 
100 Türk İngilizce öğretmeninin dikkatine sunulmuştur. Ardından öğretmenlerin görüşleri hakkında bilgi, bir anket ve yarı yapılandırılmış mülakat aracılığı ile toplanmıştır. Aynı zamanda öğretmenlerin edimbilim öğretimi için ders kitabı aktivitelerini uyarlama konusunda istekli olup olmadıkları da sorgulamaktadır. Bulgular, öğretmenlerin ders kitabı aktivitesinde yapılan değişiklikleri edimbilim öğretimi için faydalı bulduklarını göstermiştir. Ayrıca akademik eğitimleri sırasında edimbilim hakkında bir ders almış olan katılımcılar ile almayanlar arasında istatistiksel bir fark bulunmamıştır. Öğretmenler edimbilim öğretimi için materyal uyarlamanın bir zaruret olduğunu düşünmektedirler. Yine de, edimbilim konusunda yeterli bilgiye sahip olmadıkları için, katılımcıların tamamının bu tür uyarlamalar yapmadıklarını kabul etmişlerdir.

Anahtar kelimeler: Edimbilim öğretimi, ingilizce materyal uyarlaması, söz eylemleri, ricalar

\section{Introduction}

In educational contexts where English is taught as a foreign language, textbooks play a vital role. During the last three decades, textbook and curriculum writers have highlighted the communicative aspect of language (Ren \& Han, 2016). Yet, they seem to have failed to emphasise the importance of pragmatic competence within communicative competence (Karatepe, 1998; Taguchi, 2011, 2015; Wyner \& Cohen, 2015).

Pragmatic competence has two important aspects: a) learner's ability to interpret messages within a given context of situation, and b) learner's ability to use language appropriately within a given context of situation (Lo Castro, 2003; Ren \& Han, 2016). Blum-Kulka et al. (1989) argued that "Even fairly advanced language learners' communicative acts regularly contain pragmatic errors, or deficits, in that they fail to convey or comprehend the intended illocutionary force or politeness value" (p. 10).

For instance, making a request requires both knowing how to perform a request in its less facethreatening form and having the ability to use one's knowledge of vocabulary and grammar appropriately in a given context of situation (Bialystok, 1993). Such forms are usually conventionalised and cannot be produced simply by manipulating one's grammatical knowledge. Thus, learners have to learn about these conventional forms because politeness is often expressed via conventional formulae, such as 'Bless you' in English, 'Geçmiş olsun' in Turkish and 'Gute besserung' in German. Second/ foreign language learners cannot produce these forms simply by manipulating their repertoire of grammar and vocabulary (Bardovi-Harlig, 2012).

Like many other social functions of language, forms of requests have been conventionalised. That is, they have become fixed formulaic expressions, such as 'if you do not mind ('zahmet olmazsa' in Turkish)'. As a result, it is not a realistic expectation that a learner can use such conventionalised language forms by making use of his/her knowledge of lexico-grammatical resources (Karatepe, 1998, 2001). Any attempt could result in a pragmatic failure, which can potentially decrease the success of communication (Thomas, 1983). Furthermore, there is always a possibility that learners may transfer from their mother tongue by creating odd forms. Moreover, they may gradually become so accustomed to using these odd forms that it would be almost impossible to make them stop using these nonstandard forms though they come to realise that these are not appropriate and acceptable (Selinker, 1972; Wyner \& Cohen, 2015).

\begin{tabular}{|c|c|}
\hline Adres & \\
\hline RumeliDE Dil ve Edebiyat Araşttrmalar De & iDE Journal of Language and Literature Studies \\
\hline manağa Mahallesi, & ă̆a Mahallesi, Mürver Çiçeği Sokak, No:14/8 \\
\hline Kadıköy - İSTANBUL / TÜRKIYE 34 & - ISTANBUL / TURKEY 34714 \\
\hline $\begin{array}{l}\text { e-posta: editor@rumelide.com } \\
\text { tel: }+905057958124,+90216773 \text { o } 616\end{array}$ & $\begin{array}{l}\text { editor@rumelide.com, } \\
\text { +90 } 5057958124,+90216773 \text { o } 616\end{array}$ \\
\hline
\end{tabular}


Bardovi-Harlig and Mahan-Taylor (2003) argue that learners need support to learn pragmatic skills, due to the complexity in its nature. Unfortunately, any activity to increase learners' pragmatic competence is regarded as "an optional extra in a textbook syllabus" (Harwood, 2014, p.7). Many studies have been conducted to show that pragmatics lends itself to classroom teaching (Kasper, 1997; Taguchi, 2015). However, most features of pragmatics have not been included in textbooks. Even if they are included, these are misrepresentations and fail to exemplify real language use. McConnachy and Hata (2013) complained that textbooks presented stereotypical representations of pragmatic features. In addition, Vallenga (2004) found that a very limited number of speech acts are included in textbooks. Cohen and Ishihara (2013) also reported that textbooks fell short of representing pragmatic use of language.

Due to the shortcomings of textbooks regarding pragmatic aspects of the language, teachers are required to make materials adaptation for more effective pragmatics instruction. Numerous pragmatic awareness-raising exercises were suggested in the literature to enhance pragmatic instruction in EFL contexts (Crandall \& Basturkmen, 2004; Hillard, 2014; Ishihara, 2010; McConachy, 2009; Siegel, 2016; Siegel et al., 2018). These suggestions can be useful while adapting materials for teaching pragmatics. However, no studies were found investigating the views of EFL teachers' opinions about the pragmatic awareness exercises recommended in the literature. Therefore, this paper aims to investigate the views of EFL teachers on such exercises that are recommended in the literature. Also, it aims to find out their practices regarding material adaptation for pragmatics instruction.

\section{Literature review}

\subsection{Pragmatics in EFL textbooks}

Although researchers and teachers complain about the shortcomings of textbooks, they are still the most convenient resources for language teaching and learning (Tatsuki, 2019; Tomlinson, 2012). The studies which focused on the extent to which features of pragmatics have been covered reported many shortcomings. For instance, many textbooks cover only a few speech acts (Ishihara, 2010; McConnachy \& Hata, 2013; Ren \& Han, 2016; Wyner \& Cohen, 2015). Even when a speech act is included in a textbook, it only "provide[s] a very narrow range of expressions for achieving the speech acts they cover". (McConnachy \& Hata, 2013, p. 295).

In many cases, the expressions which are given as examples are unsuitable or they can only be used in particular contexts. Unfortunately, neither the students nor the teachers are provided with satisfying information on these issues. As a result, teachers end up teaching archaic expressions or expressions which could only be used in specific situations.

The most important problem in terms of pragmatics teaching and learning is that textbooks tend to present language in a decontextualised way (Karatepe \& Yllmaz, 2018; McConnachy \& Hata, 2013; Yllmaz \& Karatepe, 2013). Unfortunately, it is not uncommon to find a list of speech act expressions given in a list in many textbooks. Without a context, language is reduced to a sentence level-grammar. That is, learners see the expressions stripped of their socio-cultural variables which are related to what to say, when, and whom, and how cultural norms influence the chosen language. This reductionism limits learners' exposure to the features of pragmatics in a contextualised way (Yllmaz \& Karatepe, 2013). Wyner and Cohen (2015) argues that this leads learners to overuse one or two particular strategies and its verbalisation regardless the context of situation. Moreover, the lack of choice in

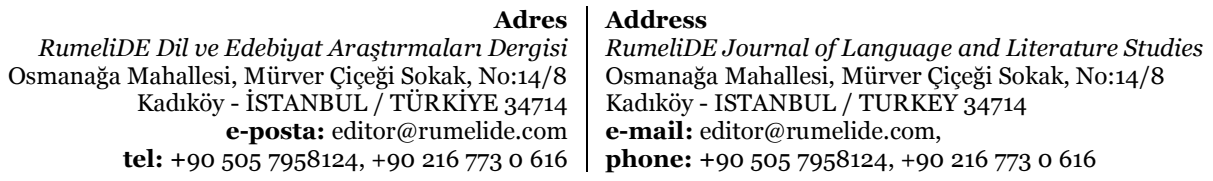


learners' repertoire causes transfer of L1 forms (Karatepe, 1998, 2001, 2016). Since textbooks usually fail to supply satisfying information on pragmatics, which creates an impression on learners and teachers that learning pragmatics is an optional task (Ren \& Han, 2016).

\subsection{Requests in textbooks}

The speech act of request attracted great attention from researchers in the field of cross-cultural and interlanguage pragmatics (Economidou-Kogetsidis, 2011; Eslami \& Liu, 2013; Karatepe, 2001, 2016; Nugroho \& Rekha, 2020). As a result, some studies examined the presentation of requests in course books. For instance, Fernández Guerra and Martinez Flor (2003) examined three proficiency-level textbooks in terms of the presentation of requests and the use of requests in three American films. After the analysis of the textbooks and films, they commented that the requests were presented in isolation at sentence level in textbooks and no instances of authentic conversations were found. Additionally, they reported that direct requests are mostly presented in textbooks. They, therefore, argued that decontextualised direct request strategies in textbooks confine learners' pragmatic competence.

Similarly, Petraki and Bayes (2013) underscored the insufficient presentation of all types of requests in textbooks. Additionally, they documented that textbooks fail to introduce an adequate number of examples to show how contextual variables impact the request strategy. They also emphasized that most textbooks lack meta-pragmatic explanations and fail to provide learners with the opportunity to practice. Due to the face-threatening nature of the speech act of request, the presentation of mitigating devices in textbooks was also analysed (Campillo, 2007). The findings revealed that textbooks overlooked most of the mitigating devices and brought attention to a few such as please.

Overall, the studies examining the presentation of requests in textbooks encountered various shortcomings that can be listed as follows:

1. The presentation of requests at sentence level rather than in a contextualised way at discourse level (Fernández Guerra \& Martỉnez Flor, 2003; Usó-Juan, 2007)

2. The lack of authentic language samples (Fernández Guerra \& Martinez Flor, 2003; Petraki \& Bayes, 2013)

3. The lack of meta-pragmatic explanations (Petraki \& Bayes, 2013)

4. The underrepresentation of mitigators (Campillo, 2007)

5. The inadequate representation of all types of requests (Barron, 2018; Petraki \& Bayes, 2013)

It has been noted that such shortcomings of textbooks regarding the presentation of the speech act of requests may bring about pragmatic errors which can potentially cause unpleasant situations in interaction (Petraki \& Bayes, 2013; Wong, 2002). Petraki and Bayes (2013) stated that the effectiveness of EFL courses regarding pragmatics instruction is based on teachers' knowledge and their enthusiasm to benefit from other resources to design materials.

\begin{tabular}{|c|c|}
\hline & \\
\hline eliDE Dil ve Edebiyat Araşttrmaları De & E Journal of Language and Literature Studies \\
\hline 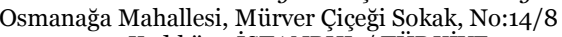 & Mahallesi, Mürver Çiçeği Sokak, No:14/8 \\
\hline Kadıköy $-\mathrm{I}$ & ISTANBUL / TURKEY 34714 \\
\hline $\begin{array}{r}\text { e-posta: editor } \\
\text { tel: }+905057958124,+9\end{array}$ & $\begin{array}{l}\text { editor@rumelide.com, } \\
\text { +90 505 7958124, +90 } 2167730616\end{array}$ \\
\hline
\end{tabular}




\subsection{Adaptation process of an activity in EFL teaching}

Teachers are expected to adapt materials and modify textbook activities. Turkish EFL teacher training programmes include an elective course on Material Development in ELT (www.yok.gov.tr ). However, it is just one semester and it has got a wide range of topics to cover such as material adaptation for teaching vocabulary, grammar, other 4 skills, and cultural issues. The materials for teaching pragmatics seem to be optional or perhaps do not exist at all.

Tatsuki (2019) reports that publishers publish textbooks with resources that will facilitate teachers' decisions on how to select the right ones for their learners. Developing their materials or modifying existing materials benefit teachers in four ways:

(1) contextualisation- creating a better fit between the context and the materials,

(2) individual need - addressing the diversity among learners and their needs,

(3) personalization- giving materials a personal touch that can increase learner engagement and appreciation, and

(4) timelines - creating materials that respond to local and global events, increasing the relevance of the lesson (Tatsuki, 2019, p. 323).

Their desire to create teaching materials to suit their learners' needs can motivate teachers, which would result in job satisfaction and increase self-confidence. Yet, are all they qualified to do this?

Bardovi- Harlig and Mossman (2017) suggest that teachers consciously look for authentic examples of appropriate and inappropriate language use examples. This way, they can create their corpus of specific language use. Learners can examine these and understand how language is used in particular situations. They explain that teachers first select a specific routine expression, and look for authentic use of these expressions to form a corpus. Then, it is recommended to prepare activities to enable learners to notice the use of target forms in specific contexts. After this step, Bardovi-Harlig and Mossman (2017) suggest creating activities to encourage learners to use these expressions.

Understandably, it is not an easy task for EFL teachers to create or modify activities for teaching pragmatics since non-native English teachers do not feel confident to decide whether an expression is appropriate or not (Cohen, 2016), and it is difficult to form a corpus for each pragmatic routine. Although plenty of pragmatic awareness-raising exercises have been suggested in the literature, there is still a huge gap in the field regarding the views of EFL teachers on such exercises and their practices related to material adaptation for teaching pragmatics. It has been underscored that teachers' beliefs have a vital role in their instructional practices (Carter \& Doyle, 1995; Johnson, 1994). Thus, we adapted a textbook activity in accordance with the recommendations made in the literature and asked the views of EFL teachers on pragmatic awareness-raising exercises. Another aspect of this paper focused on EFL teachers' opinions regarding materials adaptation for teaching pragmatics. To this end, the present research is an attempt to answer the following research questions:

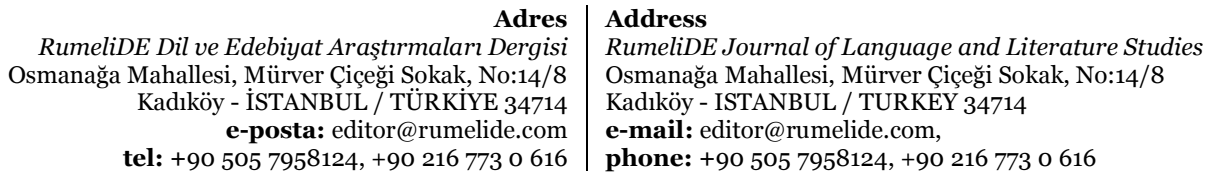

tel: $+905057958124,+902167730616$ 
1. What are the views of EFL teachers on the modifications made to a textbook activity for pragmatics instruction?

2. Is there a statistically significant difference between the views of EFL teachers who had been taught about pragmatics and the ones who had not on the modified version of the activity?

3. To what extent do EFL teachers adapt textbook activities for more effective pragmatics instruction?

\section{Methodology}

The data was collected by means of a questionnaire and an interview protocol. The study was based on a mixed methodology with a more dominant qualitative aspect (Johnson, 2007). The following sections will present details about the research methodology.

\subsection{Participants}

The participants were 100 Turkish EFL teachers (21 male and 79 female) who were teaching English to different age groups in Turkey (see Table 1). The participants were accessed via "snowball sampling" (Cohen et al., 2007, p. 116). The sample consisted of both novice and experienced teachers. However, the majority (\%72) were inexperienced teachers with $0-3$ years of teaching experience. Their age ranged from 22 to 49 . The EFL teachers who had been taught about pragmatics during their academic studies (43\%) were outnumbered by the ones who had not (57\%).

Table 1. Information about participants

\begin{tabular}{lll}
\hline Workplace & Female & Male \\
\hline Primary school & 13 & 1 \\
Middle school & 15 & 6 \\
High school & 20 & 7 \\
University & 10 & 2 \\
Private language course & 4 & 1 \\
Freelance & 17 & 4 \\
Total & 79 & 21 \\
\hline
\end{tabular}

\subsection{The modification procedure of the textbook activity}

A dialogue activity from an EFL textbook, which was published by the Turkish National Ministry of Education, was adapted by the authors. The purpose of the original activity was to enable learners to recognize and perform appropriate requests. Before the adaptation process, the shortcomings of the activity in terms of teaching pragmatics were first determined by the researchers by reviewing the relevant literature (McConachy, 2009; Ishihara, 2010, 2011; Tran \& Yeh, 2020; Yllmaz \& Karatepe, 2013). Then, the modifications were made to the activity considering the recommendations that were presented in the previous research (Crandall \& Basturkmen, 2004; Ishihara, 2010; McConachy, 2009; McConachy \& Hata, 2013; Schmidt, 1990; Siegel, 2016; Siegel et al., 2018; Yllmaz \& Karatepe, 2013).

\begin{tabular}{|c|c|}
\hline Adres & Address \\
\hline RumeliDE Dil ve Edebiyat Araşturmaları Dergisi & RumeliDE Journal of Language and Literature Studies \\
\hline Osmanağa Mahallesi, Mürver Çiçeği Sokak, No:14/8 & Osmanağa Mahallesi, Mürver Çiçeği Sokak, No:14/8 \\
\hline 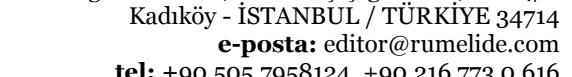 & $\begin{array}{l}\text { Kadıköy - ISTANBUL / TURKEY } 34714 \\
\text { e-mail: editor@rumelide.com, }\end{array}$ \\
\hline
\end{tabular}


When the original activity was examined, it was determined that its content was presented in a decontextualised way. However, the importance of presenting language material in a context has been emphasised by different studies (McConnachy,2009; Yllmaz \& Karatepe, 2013). To overcome this constraint, two of the five contextualisation strategies personalisation and individualisation, described by Yllmaz and Karatepe (2013), were employed. Yllmaz and Karatepe (2013) underscored that implementing such strategies enabled learners to relate lesson content to their lives which makes the learning process more meaningful for learners. A close look at the activity revealed that learners are not provided with sufficient information about the contextual factors which affect the language use in the dialogue. McConachy (2009) also marked this issue as one of the major shortcomings of textbooks. Siegel (2016) argued that contextual information enables learners to understand the pragmatic dimensions. As a result, the modified activity also included information about the contextual factors, such as where the interaction takes place, the relationship between the interlocutors, and the background of interlocutors, etc.

When the dialogue is thoroughly examined, it was realized that the original activity was unsatisfactory in terms of presenting various pragmatic language samples. What is more, the original dialogue seems like a list of requests in isolation. According to Ishihara and Cohen (2010) and the Center for Advanced Research on Language Acquisition (2015), a speech act set consists of three elements: attention getters (alerters), head act (the request itself), and supportive moves (explanatory sentences for the request). However, the original activity is insufficient in terms of presenting requests within a speech act set and other types of pragmatic language samples such as conversation openers, softeners, etc. Thus, the original dialogue was enriched with additional conversation openers, direct and indirect requests, supportive moves, idiomatic expressions, and softeners, etc.

The original activity did not have any aim to increase learners' meta-language skills. In order to compensate for this, learners were asked to underline the requests they recognised in the dialogue. This exercise was based on Schmidt's (1990) Noticing Hypothesis (see also McConnacy, 2009).

In the following part of the modification process, some discussion questions about the requests presented in the dialogue were added to increase learners' meta-pragmatic awareness (e.g. Why do you think David used different request forms in each situation?, Do you think David is being polite or impolite? Why?, Would you behave in the same way? Why?). These questions were developed in accordance with the recommendations made by McConachy (2009), Crandall and Basturkmen (2004), and Siegel et al. (2018). The discussion questions presented in the modified activity can be defined as referential questions that explore learners' thoughts and perceptions about the presented requests. Thus, answers are unknown to the teacher. Brophy and Good (1991) put forward the characteristics of a good teacher question as clear, brief, natural, purposeful, sequenced, and thought-provoking. While designing the discussion questions, Brophy and Good's (1991) description of a good question was taken into account.

In the next stage of the modification process, a comparative stage was added to enable learners to create a dialogue for the same situation in their mother tongue and some "comparative questions" (McConachy, 2009, p. 122) were added (e.g. What are the differences between the two dialogues?, Why do you think these differences occur between the two languages?). Such exercises are expected to enable learners to recognize the differences in the pragmatic norms of the target culture and learners' own. Recognition of such differences can make learners more aware of possible pragmatic errors due to pragmatic transfers from their L1.

\footnotetext{
RumeliDE Dil ve Edebiyat Araşttrmaları Dergisi Osmanağa Mahallesi, Mürver Ciçeği Sokak, No:14/8 Kadıköy - ÍSTANBUL / TÜRKIYE 34714 e-posta: editor@rumelide.com tel: +90 505 7958124, +90 2167730616 
The next stage of the modification process lead learners to focus on the other language items, namely conversation openers (e.g. How is it going?), idiomatic expressions (e.g. What's up, what about you) supportive moves (e.g. I know you're too busy nowadays), and softeners (e.g. kind of, a little, please).

In the production stage of the modified activity, a few Discourse Role-Play Tasks (DRPT) were added. While performing these, learners were asked to use various pragmatic language items such as 'conversation openers', 'attention getters', 'supportive moves', and 'softeners'. The additional DRPT exercises were enriched by means of visuals so that learners could understand the context of situation better. With the help of these visuals, it was aimed that learners' schemata would be stimulated and the interaction would be more intriguing for them (Siegel, 2016).

In the final part of the adapted activity, learners were asked to discuss the appropriateness of requests produced by their peers in DRPTs. Such reflective discussions may be useful to foster learners' metapragmatic awareness (McConachy \& Hata, 2013). Furthermore, such exercises provide learners with the opportunity to receive feedback from both their peers and the teacher.

\subsection{Instruments and data collection procedure}

The participants were requested to fill in a questionnaire with 19 statements after examining the original textbook activity and its modified version. They were contacted via email and WhatsApp and asked if they would volunteer to support our study. Those who agreed to do so were sent the link of the questionnaire which was made as a Google Document and a supplementary file where they saw the original activity and its modified version. After the completion of the questionnaire, they were contacted and asked to take part in the interview protocol. Following this, interviews were conducted with 12 participants to elicit further information on their specific views on the adapted activity.

\subsubsection{The questionnaire}

The questionnaire was designed by the researchers. The questionnaire included items for each modification made to the original textbook activity. It aimed to collect information about the participants' views on the modifications explained above. Additionally, the questionnaire also consisted of a part seeking demographic information about the participants such as their age, gender, academic background regarding pragmatics, years of experience, workplace, etc.

The initial version of the questionnaire consisted of 29 statements. In order to establish both content and face validity, expert judgement was employed. The questionnaire, the original textbook activity, and the modified version of the activity were given to five experts in the field. Three of these experts are lecturers in the ELT department of a Turkish university. Two of these lecturers had a PhD degree in Pragmatics. The other lecturer has been teaching Materials Development and Evaluation course for many years. One of the experts is a native-speaker English teacher who used to teach in Turkey. She is currently teaching English for Academic Purposes at a private language institution in the UK. The other expert had an MA degree in ELT and has been teaching at a public university for years. After consulting their opinions, the items related to the overall look of the modified activity (e.g. sequence of the activities, the layout) were found irrelevant for the purpose of this research. As a result, the number of items in the questionnaire was reduced to 19. Furthermore, the presentation of the terminology related to pragmatics (e.g. head act) was revised and rewritten. Such changes made the questionnaire items easy to understand for the teachers who did not know much about the field of

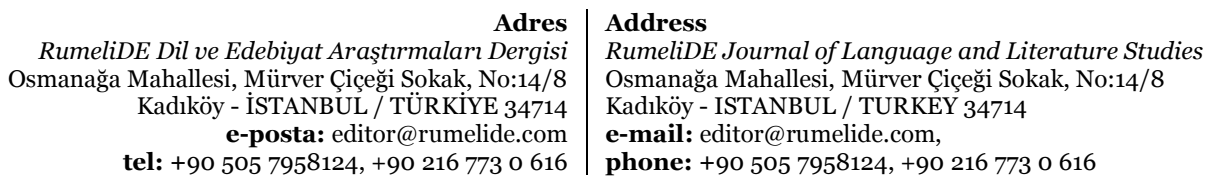


pragmatics. The final version of the questionnaire was given to 8 EFL teachers who were not the actual participants of the study and they were asked to evaluate the questionnaire items in terms of their clarity. All the teachers agreed on the clarity of the statements.

\subsubsection{The interview protocol}

"A semi-structured interview" (Cohen et al., 2007, p.361) was conducted with 12 participants on the phone. While half of the interviewees took a pragmatics course during their academic studies, the others did not. The second author contacted them and recorded the conversations on another smartphone. The interviews lasted from 12 to 16 minutes. All interviewees were asked the same openended questions. This increased the "comparability of the data" (ibid., P. 353). These questions aimed to "...elicit descriptions of specific situations and actions" (ibid., P. 355) regarding teaching and learning pragmatics and requests in the Turkish EFL context. In addition, the interview protocol aimed to find out to what extent EFL teachers make similar adaptations for teaching pragmatics.

\subsection{Data analysis procedure}

SPSS 26 was used to calculate the reliability score of the questionnaire and it was found highly reliable (Cronbach's $\alpha=.89$ ). In order to analyse the questionnaire data regarding the first research question, descriptive statistics for each item were calculated. The skewness and kurtosis values were found between -1.5 and +1.5 which means the data was normally distributed (Tabachnick \& Fidell, 2013). Therefore, an independent samples t-test, which is a parametric test, was run so as to find out the difference between the views of teachers who took a pragmatics course during their university education and those who did not. Interview findings were also used to get in-depth information about the research questions 1 and 2. In order to answer the research question 3, only the interview data was used. For the interview data analysis, the recorded interviews were partially transcribed and the recurring themes were identified.

\section{Results}

In this part, the results of the data obtained from the questionnaire and the interviews will be presented. In order to investigate the views of EFL teachers on pragmatic awareness-raising exercises in the adapted activity, descriptive statistics of each questionnaire item were calculated. Descriptive statistics demonstrated that the majority of the participants (96\%) agreed that the adapted version of the activity could enable students to learn requests better (Item 2). In addition, the first item had the highest mean score (4.76). That is, all the participants supported the view that requests should be presented in a contextualized way. Interview results also demonstrated that EFL learners have positive opinions about the contextualisation strategies, namely personalisation and individualisation (Karatepe \& Yllmaz, 2018) employed in the adapted version of the activity as seen in Table 2.

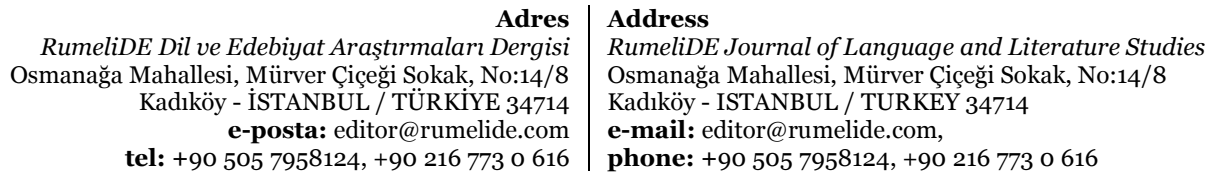

tel: +90 505 7958124, +90 2167730616 
Table 2. The opinions of EFL teachers about the contextualization strategies in the modified activity

\begin{tabular}{ll}
\hline Themes & Frequency \\
\hline Individualisation provides learners with a more engaging and safe learning environment. & 5 \\
Individualisation enables learners to learn from their peers. & 5 \\
Personalisation makes the lesson content more meaningful for learners. & 4 \\
Personalisation enables learners to relate the lesson content to their lives. & 6 \\
The use of contextualization strategies prepares learners for the lesson content. & 8 \\
\hline
\end{tabular}

Descriptive statistics of the questionnaire items regarding the changes made to the textbook dialogue are presented in Table 3 where numbers indicate that most of the participants' opinions are in favour of the modifications made to the dialogue. Furthermore, most of the interviewees stated that pragmatic items such as conversation openers, idiomatic expressions, supportive moves, etc. both help learners gain pragmatic awareness and make the dialogue sound more natural. However, few interviewees claimed that those modifications made the dialogue a lot more complex than the original activity.

Table 3. The opinions of EFL teachers about the modifications made to the dialogue

\begin{tabular}{|c|c|c|c|c|c|}
\hline \multirow[t]{2}{*}{ Item } & \multicolumn{3}{|c|}{ Percent (\%) } & \multirow[t]{2}{*}{ M } & \multirow[t]{2}{*}{ SD } \\
\hline & $\mathrm{D}$ & $\mathrm{N}$ & A & & \\
\hline $\begin{array}{l}\text { 3. I believe exposing students to direct and indirect request- } \\
\text { making strategies in the same activity will not be a problem. }\end{array}$ & 6.0 & 25.0 & 69.0 & 3.92 & 0.95 \\
\hline $\begin{array}{l}\text { 7. In my opinion, including supportive moves in the dialogue } \\
\text { increases students' awareness about how to make a request. }\end{array}$ & 2.0 & 7.0 & 91.0 & 4.45 & 0.71 \\
\hline $\begin{array}{l}\text { 8. I believe including pragmatic items in the dialogue such as } \\
\text { conversation openers increases the awareness of students about } \\
\text { appropriate conversation behaviour. }\end{array}$ & $\mathrm{O}$ & 8.0 & 92.0 & 4.64 & 0.62 \\
\hline $\begin{array}{l}\text { 9. I believe including pragmatic items, such as idiomatic } \\
\text { expressions increases the awareness of students about pragmatic } \\
\text { language use. }\end{array}$ & 6.0 & 3.0 & 91.0 & 4.44 & 0.85 \\
\hline $\begin{array}{l}\text { 10. In my opinion, including pragmatic items, such as } \\
\text { conversation openers make the dialogue sound more authentic. }\end{array}$ & 1.0 & 4.0 & 95.0 & 4.44 & 0.85 \\
\hline $\begin{array}{l}\text { 11. I think including idiomatic expressions makes the language of } \\
\text { the dialogue sound more natural. }\end{array}$ & 2.0 & 6.0 & 92.0 & 4.63 & 0.91 \\
\hline
\end{tabular}

In order to explore the opinions of EFL teachers about the dialogue-related pragmatic awarenessraising exercises added to the activity in the modification process, descriptive statistics of the relevant questionnaire items were presented in Table 4.

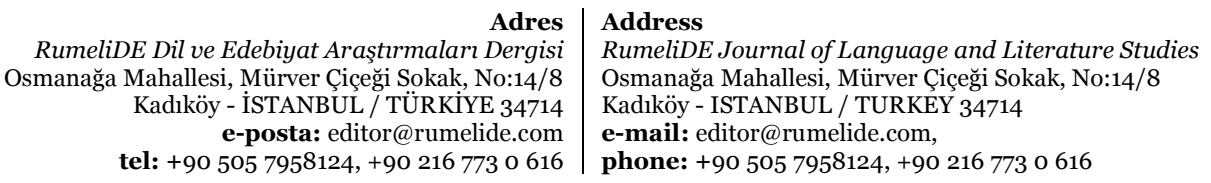


904 / RumeliDE Journal of Language and Literature Studies 2021.23 (June)

A case study on EFL teachers' views on material adaptation for teaching pragmatics / Ç. Karatepe; M. Civelek (pp. 894-910)

Table 4. The opinions of EFL teachers about the dialogue-related pragmatic awareness-raising activities

\begin{tabular}{|c|c|c|c|c|c|}
\hline \multirow[t]{2}{*}{ Item } & \multicolumn{3}{|c|}{ Percent (\%) } & \multirow[t]{2}{*}{ M } & \multirow[t]{2}{*}{ SD } \\
\hline & $\mathrm{D}$ & $\mathrm{N}$ & A & & \\
\hline $\begin{array}{l}\text { 4. I believe helping students notice the difference between direct } \\
\text { and indirect requests in the activity increases their awareness of } \\
\text { appropriate language use. }\end{array}$ & 2.0 & 8.0 & 90.0 & 4.50 & 0.73 \\
\hline $\begin{array}{l}\text { 5. I think focusing on the modal verbs in the interrogative } \\
\text { structure of the requests in the dialogue will enable students to be } \\
\text { more aware of their use in a request. }\end{array}$ & 3.0 & 12.0 & 85.0 & $4 \cdot 37$ & 0.81 \\
\hline $\begin{array}{l}\text { 6. I think focusing on the politeness markers such as 'please' in the } \\
\text { dialogue will help raise students' awareness of appropriate } \\
\text { language use. }\end{array}$ & 2.0 & 8.0 & 90.0 & 4.58 & 0.72 \\
\hline $\begin{array}{l}\text { 12. I think asking discussion questions about the use of different } \\
\text { requesting strategies helps students learn different request } \\
\text { strategies. }\end{array}$ & 1.0 & 3.0 & 96.0 & 4.55 & 0.70 \\
\hline $\begin{array}{l}\text { 13. I believe comparing the performance of requests in Turkish } \\
\text { and English help students recognize the social and cultural norms } \\
\text { of English. }\end{array}$ & 11.0 & 18.0 & 71.0 & 4.50 & 0.65 \\
\hline
\end{tabular}

As Table 4 shows, a greater number of participants demonstrated positive attitudes towards the dialogue-related pragmatic awareness-raising exercises such as bringing attention to the difference between direct and indirect requests $(\mathrm{M}=4.50)$, focusing attention on the use of modal verbs in head acts $(M=4.37)$, emphasizing the use of politeness markers $(M=4.58)$, asking discussion questions associated with different request making strategies $(\mathrm{M}=4.55)$, and cross-checking the use of requests in Turkish and English $(M=4.50)$. In addition, this is supported with the information elicited through the interviews. That is, the majority agreed that such exercises could benefit learners' pragmatic competence. Yet, a few expressed their hesitations about the use of Turkish to teach pragmalinguistic features of English. Finally, a small number of the interviewees claimed that such exercises made the lesson content more complex for their learners.

In order to investigate EFL teachers' opinions about the modifications made to the production stage of the activity, descriptive statistics of the associated questionnaire items were shown in Table 5.

Table 5. The opinions of EFL teachers about the modifications made to the production stage

\begin{tabular}{|c|c|c|c|c|c|}
\hline \multirow[t]{2}{*}{ Item } & \multicolumn{3}{|c|}{ Per cent (\%) } & \multirow[t]{2}{*}{$\mathrm{M}$} & \multirow[t]{2}{*}{ SD } \\
\hline & $\mathrm{D}$ & $\mathrm{N}$ & $\mathrm{A}$ & & \\
\hline $\begin{array}{l}\text { 14. I think using Discourse Role-Play Tasks at the end of the } \\
\text { activity enables teachers to check learners' comprehension of } \\
\text { different requesting strategies. }\end{array}$ & 1.0 & 6.0 & 93.0 & 4.57 & 0.65 \\
\hline $\begin{array}{l}\text { 15. I think using Discourse Role-Play Tasks at the end of the } \\
\text { activity provides students with the opportunity to practice. }\end{array}$ & 1.0 & 5.0 & 94.0 & 4.62 & 0.63 \\
\hline $\begin{array}{l}\text { 16. I think the visuals presented with Discourse Role-Play Tasks } \\
\text { enable learners to understand the context of situation. }\end{array}$ & 4.0 & 8.0 & 88.0 & 4.42 & 0.80 \\
\hline $\begin{array}{l}\text { 17. I believe discussing the appropriateness of requests produced } \\
\text { by students enables learners to learn from their peers. }\end{array}$ & 3.0 & 10.0 & 87.0 & 4.36 & 0.85 \\
\hline $\begin{array}{l}\text { 18. I believe discussing the appropriateness of requests produced } \\
\text { by students raises their consciousness about language use. }\end{array}$ & 5.0 & 8.0 & 87.0 & $4 \cdot 33$ & 0.90 \\
\hline $\begin{array}{l}\text { 19. I believe discussing the appropriateness of requests produced } \\
\text { by students provides them with effective feedback from their peers }\end{array}$ & 2.0 & 14.0 & 84.0 & 4.36 & 0.83 \\
\hline
\end{tabular}

\begin{tabular}{r|l} 
Adres & Address \\
RumeliDE Dil ve Edebiyat Araşttrmaları Dergisi & RumeliDE Journal of Language and Literature Studies \\
Osmanağa Mahallesi, Mürver Çiçeği Sokak, No:14/8 & Osmanağa Mahallesi, Mürver Çiçeği Sokak, No:14/8 \\
Kadıköy - İSTANBUL / TÜRKIYE 34714 & Kadıköy - ISTANBUL / TURKEY 34714 \\
e-posta: editor@rumelide.com & e-mail: editor@rumelide.com, \\
tel: +90 505 7958124, +90 2167730616 & phone: +90 505 7958124, +90 216773 o 616
\end{tabular}


and the teacher.

As Table 5 demonstrates, the majority of EFL learners agree that DRPTs are valuable tools so as to check learners' comprehension ( $M=4.57)$ and enable learners to practice $(M=4.62)$. Moreover, they also agree that presenting DRPTs with pictures helps learners comprehend the context of situation (4.42). Additionally, the qualitative findings indicate that DRPTs are the most favoured exercise among the others in the adapted activity since such exercises enable learners to practice different requesting strategies in various contexts. However, they also argue that including DRPTs in crowded language classrooms would be difficult. In addition, questionnaire findings documented that the participants also had mostly positive attitudes towards discussing the appropriateness of requests performed by learners in DRPTs.

In order to investigate whether there is any statistically significant difference between the views of EFL teachers who had been taught about pragmatics and the ones who had not, an independent samples ttest was run. The t-test results revealed that there was no statistically significant difference between the opinions of EFL teachers who had been taught about pragmatics $(M=4.49)$ and the ones who had not $(M=4.41)$, about the modifications made to the textbook activity $(\mathrm{p}=0.402>0.05)$.

Another aim of this research was to explore to what extent EFL teachers adapt activities for pragmatics instruction. Qualitative findings revealed that none of the interviewees thought textbook activities were effective enough to teach pragmatic aspects of the language. Interestingly, it was also seen that none of them has made such adaptations for teaching pragmatics more effectively. Nevertheless, they expressed some reasons for not making such modifications. The reasons stated during the interviews are presented in Table 6.

Table 6. The reasons why EFL teachers do not adapt materials for pragmatics instruction

\begin{tabular}{ll}
\hline Reason & Frequency \\
\hline Lack of knowledge regarding pragmatics & 9 \\
Heavy workload & 4 \\
Test-oriented education system & 3 \\
Lack of time & 2 \\
Learners' low proficiency level & 3 \\
\hline
\end{tabular}

As Table 6 indicates, interview findings reveal that the majority of the interviewees do not think they are capable of making material adaptation for pragmatics instruction due to their inadequate knowledge. In addition to this, other reasons are heavy workload, a test-oriented education system, lack of time, and learners' low language proficiency.

\section{Discussion}

This paper sought to investigate the views of EFL teachers on an adapted textbook activity for pragmatics instruction. Both qualitative and quantitative findings revealed that EFL teachers had positive views on the modifications made to the activity. In other words, they demonstrated highly positive attitudes towards the pragmatic awareness-raising exercises recommended in the field. For illustration, nearly all of them agreed that requests should be presented in a contextualized way. They stated that contextualization strategies employed in the modified version of the activity were valuable

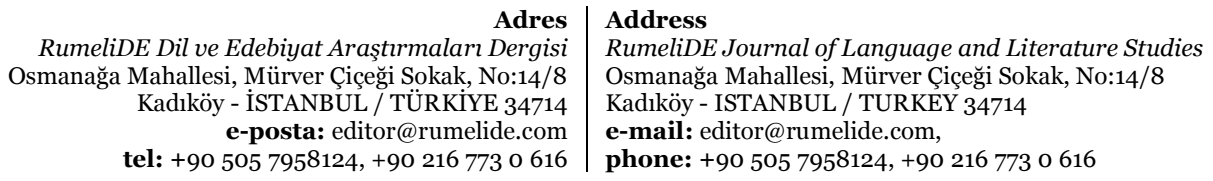


tools to prepare learners for the actual lesson content. Similarly, Hadley (2003) commented that contextualization strategies enabled learners to relate the lesson content to their experiences. The significance of contextualization for language education was also underlined in the previous studies (Karatepe \& Yllmaz, 2018; Opp-Beckman \& Klinghammer, 2006; Yılmaz \& Karatepe, 2013).

Furthermore, the EFL teachers expressed positive opinions about the additions made to the dialogue. The researchers attempted to make it richer by adding a variety of components as explained previously. The EFL teachers declared that the original textbook dialogue seemed a poor representation of pragmatic aspects of the language. They also remarked that the original textbook dialogue did not sound natural. In line with this finding, the lack of authenticity in textbook dialogues was also underscored by EFL teachers in Japan (Ishihara, 2011). Furthermore, Tran and Yeh (2020) stated that EFL textbook dialogues tend to present lexico-grammatical patterns in the sentence level and fail to emphasize the social use of speech acts presented.

The EFL teachers also expressed positive attitudes towards the additional dialogue-related pragmatic awareness-raising exercises. Such exercises can be listed as focusing on the use of direct and indirect requests in the dialogue, focusing attention on the use of modal verbs and politeness markers, discussing the use of different request-making strategies, and comparing the use of requests in Turkish and English. These exercises have also been recommended in the previous research as useful methods to foster learners' pragmatic language use (Crandall \& Baturkmen, 2004; Ishihara, 2010; McConachy, 2003; Siegel et al., 2018).

Similarly, they praised the changes made to the production stage of the activity. DRPTs were found to be the most favoured exercise in the modified version of the activity. They commented that DRPTs were practical tools to enable learners to practice the newly-learnt language features as recommended in the literature (Crandall \& Baturkmen, 2004; McConachy \& Hata, 2013; Siegel, 2016). Furthermore, they articulated that discussing the appropriateness of requests produced by the learners in DRPTs could be effective to foster learners' appropriate language use and provide them with feedback. Furthermore, no statistically significant difference was found between the views of EFL teachers who took a course on pragmatics and the ones who did not.

The current research also aimed to find out EFL teachers' practices regarding materials adaptation for teaching pragmatics. The findings indicated that they were aware of the importance of pragmatics in language teaching, and they agreed that the features of pragmatics were under-represented in textbooks. They, nevertheless, seemed to be reluctant to modify an activity for this purpose. They gave several reasons for this, namely lack of time, heavy workload, learners' proficiency level, and examoriented system. However, the most important reason was that they did not feel confident enough to modify a textbook activity to teach pragmatics. Even those who took the pragmatics course admitted to that. Cohen's (2016) findings also indicated that non-native language teachers fall short in terms of pragmatic instructional practices. Moreover, Ylldız-Ekin and Atak-Damar (2013) documented that EFL teacher training programs fail to equip prospective teachers with the necessary knowledge and skills for pragmatics classroom practices.

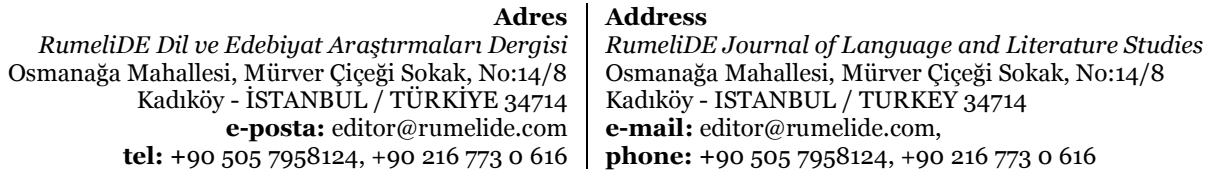

tel: +90 505 7958124, +90 2167730616 


\section{Conclusion}

This paper aimed at finding out the views of a group of EFL teachers on a dialogue activity, which was modified in accordance with the recommendations made in the field. Due to the shortcomings of EFL textbooks regarding pragmatic language presentation and instruction, it has become compulsory for EFL teachers to make material adaptations to provide learners with effective pragmatics instruction. Several pragmatic awareness-raising exercises were recommended in the field for teaching pragmatics.

The findings showed that EFL teachers possessed positive views on the modifications made to the textbook activity. In other words, they found pragmatic awareness-raising exercises recommended in the field useful for pragmatics instruction. Additionally, no significant difference was found between the views of EFL teachers who had taken a course related to pragmatics and the ones who had not.

The results also indicated that topics related to teaching the features of pragmatics were not fully represented in teacher training programmes (Ishihara, 2011; Glaser, 2018; Karatepe, 1998, 2001, 2016). Since even the teachers who had taken a pragmatics-related course did not feel confident enough to make materials adaptation, a specific aspect of creating/adapting materials for the purpose of teaching pragmatics could be integrated into the existing courses in teacher training programmes. This component needs to focus specifically on the teaching of the features of pragmatics such as a speech act, or a conversational management skill, or the use of a formulaic expression. Student teachers should be equipped with the knowledge of pragmatics to qualify fully as professionals.

Ishihara (2011) underscored the vital role of subject-matter knowledge for teaching pragmatics. In order to modify existing materials to add features of pragmatics, teachers need to know about pragmatics. However, it is not easy to put this knowledge into practice in the process of materials modification. Teachers need to gain a linguistic perspective of language. At present, Turkish EFL teacher training programmes fail to give student teachers this perspective.

\section{End notes}

1. An earlier version of this study was presented at IVth International Conference on Research in Applied Linguistics (ICRAL2020). 24- 26 Oct., 2020, Bursa, Turkey.

2. We would like to thank our colleagues; without whose assistance, we could not have carried out this study.

\section{References}

Bardovi- Harlig, K. (2012). Formulas, routines, and conventional expressions in pragmatics research, Annual Review of Applied Linguistics , Vol. 32 , pp. 206 - 227. DOI: https://doi.org/10.1017/So267190512000086

Bardovi-Harlig, K., \& Mahan-Taylor, R. (2003). Teaching pragmatics. Washington, DC: US Department of State, Office of English Language Programs.

Bardovi-Harlig, K., \& Mossman, S. (2017). Corpus-based materials development for teaching and learningpragmatic routines. In B. Tomlinson (Ed.), SLA research and materials development for language learning (pp. 250-267). New York: Routledge.

Bialystok, E. (1993). Metalinguistic awareness: The development of children's representations of language. In C. Pratt \& A. Garton (Ed.), Systems of representation in children: Development and use (pp. 211- 233). London: Wiley.

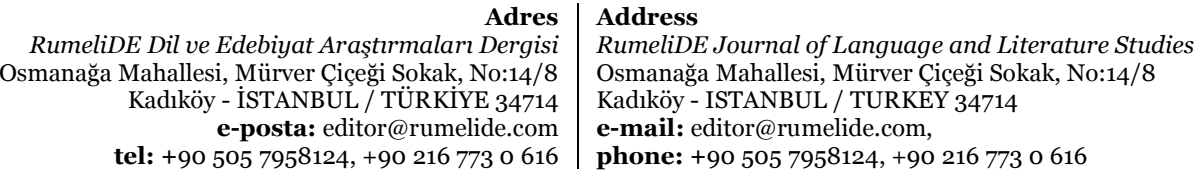


Blum-Kulka, S., House, J., \& Kasper G. (1989). Cross-cultural pragmatics: Requests and apologies. Norwood, NJ: Ablex Publishing Corporation

Brophy, J. E., \& Good, T. L. (1991). Looking in classrooms (5th ed.). New York: HarperCollins.

Campillo, P. S. (2008). Examining mitigation in requests: A focus on transcripts in ELT coursebooks. In Intercultural language use and language learning (pp. 207-222). Springer, Dordrecht.

Carter, K., \& Doyle, W. (1995, June). Preconceptions in learning to teach. In The Educational Forum (Vol. 59, No. 2, pp. 186-195). Taylor \& Francis Group.

Center for Advanced Research on Language Acquisition (2015). Pragmatics and speech acts. University of Minnesota: Center for Advanced Research on Language Acquisition. Retrieved from www.carla.umn.edu/speechacts/index.html

Cohen, A. D. (2016). The teaching of pragmatics by native and nonnative language teachers: What they know and what they report doing. Studies in Second Language Learning and Teaching, 6(4), 561-585.

Cohen, A. D. \& Ishihara, N. (2013). Pragmatics. In Tomlinson, B. (Ed.) Applied Linguistics and Materials Development. London: Bloomsbury.

Cohen, L. , Manion, L. \& Morrison, K. (2007). Research Methods in Education (6 ${ }^{\text {th }}$ edition). London: Routledge.

Crandall, E., \& Basturkmen, H. (2004). Evaluating pragmatics-focused materials. ELT journal, 58(1), 38-49.

Economidou-Kogetsidis, M. (2011). Please answer me as soon as possible: Pragmatic failure in nonnative speakers' e-mail requests to faculty. Journal of Pragmatics, 43(13), 3193-3215.

Eslami, Z. R. \& Liu, C. (2013). Learning Pragmatics through Computer-Mediated Communication in Taiwan. Iranian Journal of Society, Culture, \& Language, 1(1), 52-73

Fernández Guerra, A., \& Martinez Flor, A. (2003). Requests in films and in EFL textbooks: A comparison. ELIA, 4, 17-34.

Ishihara, N. (2011). Co-constructing pragmatic awareness: Instructional pragmatics in EFL teacher development in Japan. TESL-EJ, 15 (2). Retrieved from http://www.teslej.org/wordpress/issues/volume15/ej58/ej58a2/.

Ishihara, N. (2010). Adapting textbooks for teaching pragmatics. In N. Ishihara \& A. D. Cohen (Ed.), Teaching and Learning Pragmatics: Where Language and Culture Meet (pp. 145-166). Edinburg: Pearson Education.

Ishihara, N., \& Cohen, A. D. (2010). Describing speech acts: Linking research and pedagogy. In N. Ishihara \& A.D. Cohen (Ed.), Teaching and Learning Pragmatics: Where Language and Culture Meet (pp. 56-74).Edinburg: Pearson Education

Glaser, K. (2018). Enhancing the role of pragmatics in primary English teacher training. Glottodidactica. An International Journal of Applied Linguistics, 45(2), 119-131.

Hadley, A.O. (2003). Teaching Language in Context. ( $3^{\text {rd }}$ Ed.). Boston: Heinle\&Heinle.

Harwood, N. (2014). Content consumption and production: three levels of textbook research. In Harwood, N. (Ed.) English Language Teaching Textbooks: Content, consumption, production. Basingstoke: Palgrave \& MacMillan.

Hilliard, A. (2014). Spoken grammar and its role in the English language classroom. English Teaching Forum. Vol. 4: 2-13.

Johnson, K. E. (1994). The emerging beliefs and instructional practices of preservice English as a second language teachers. Teaching \& Teacher Education, 10 (4): 439-452.

Johnson, R. B. (2007). Toward a definition of mixed methods research. Journal of Mixed Methods Research, 1(2), 112-133.

\begin{tabular}{r|l} 
Adres & Address \\
RumeliDE Dil ve Edebiyat Araşttrmaları Dergisi & RumeliDE Journal of Language and Literature Studies \\
Osmanağa Mahallesi, Mürver Çiçeği Sokak, No:14/8 & Osmanağa Mahallesi, Mürver Çiçeği Sokak, No:14/8 \\
Kadıköy - ISTANBUL / TÜRKIYE 34714 & Kadıköy - ISTANBUL / TURKEY 34714 \\
e-posta: editor@rumelide.com & e-mail: editor@rumelide.com, \\
phone: +90 505 7958124, +90 2167730616
\end{tabular}


Karatepe, Ç. (1998). Teaching pragmalinguistics in teacher training programmes. PhD dissertation, University of Liverpool. Liverpool, UK.

Karatepe, Ç. (2001). Pragmalinguistic awareness in EFL teacher training. Language Awareness, 2(3), 178-188.

Karatepe, Ç. (2016). Indirectness in requests in complaint letters to the higher institution by Turkish EFL students. Procedia-Social and Behavioral Sciences, 232, 354-361. DOI: 10.1016/j.sbspro.2016.10.050

Karatepe, Ç., \& Yllmaz, D. (2018). Promoting structured reflectivity in teacher education: An innovative approach. Journal of Teacher Education and Educators, 7(1), 57-74.

Kasper, G. (1997). Can pragmatics be taught. In Plenary speech presented at the Annual TESOL Convention (March, the 32nd conference, international), Orlando, Florida.

Lo Castro, V. (2003). An introduction to pragmatics: Social action for language teachers. Michigan, USA: The University of Michigan Press.

McConachy, T. (2009). Raising sociocultural awareness through contextual analysis: Some tools for teachers. ELT journal, 63(2), 116-125.

McConachy, T., \& Hata, K. (2013). Addressing textbook representations of pragmatics and culture. ELT Journal, 67(3), 294-301.

Nugroho, A., \& Rekha, A. (2020). Speech acts of requests: A case of Indonesian EFL learners. Journal of English Language Teaching and Linguistics, 5(1), 1-16.

Opp-Beckman, L., \& Klinghammer, S. J. (2006). Shaping the way we teach English: Successful practices the world. Publication Office of English Language Programs, Department of State: Washington, DC.

Petraki, E., \& Bayes, S. (2013). Teaching oral requests: An evaluation of five English as a second language coursebooks. Pragmatics, 23(3), 499-517.

Ren, W. \& Han, Z. (2016). The representation of pragmatic knowledge in recent ELT textbooks. ELT Journal. 1-11.

Schmidt, R. W. (1990). The role of consciousness in second language learning. Applied linguistics, 11(2), 129-158.

Selinker, L. (1972). Interlanguage. IRAL, X73, 209-231.

Siegel, J. (2016) Pragmatic activities for the speaking classroom. English Teaching Forum, pp.1219. Retrieved from http://www.americanenglish.state.gov/english-teaching-forum

Siegel, J., Broadbridge, J., \& Firth, M. (2019). Saying it 'just right': teaching for pragmatic success in ELT. ELT Journal, 73(1), 31-40.

Tabachnick, B. G., \& Fidell, L. S. (2013). Using multivariate statistics (6th ed.). Boston, MA: Pearson Education.

Taguchi, N. (2011). Teaching pragmatics: Trends and issues. Annual Review of Applied Linguistics, 31, 289-310.

Taguchi, N. (2015). Instructed pragmatics at a glance: where instructional studies were, are, and should be going. Language Teaching 48(1), 1-50.

Tatsuki, D. (2019). Instructional material development in L2 pragmatics. In N. Taguchi (Ed.), The Routledge handbook of SLA and pragmatics (pp. 322-337). New York: Routledge. https://doi.org/10.4324/9781351164085-21

Thomas, J. (1983). Cross-cultural pragmatic failure. Applied linguistics, 4(2), 91-112.

Tomlinson, B. (2012). Materials development for language learning and teaching. Language Teaching, 45(2): 143-179.

\begin{tabular}{|c|c|}
\hline & \\
\hline eliDE Dil ve Edebiyat Araşttrmaları De & E Journal of Language and Literature Studies \\
\hline 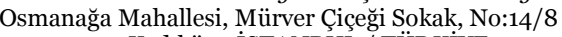 & Mahallesi, Mürver Çiçeği Sokak, No:14/8 \\
\hline Kadıköy $-\mathrm{I}$ & ISTANBUL / TURKEY 34714 \\
\hline $\begin{array}{r}\text { e-posta: editor } \\
\text { tel: }+905057958124,+9\end{array}$ & $\begin{array}{l}\text { editor@rumelide.com, } \\
\text { +90 505 7958124, +90 } 2167730616\end{array}$ \\
\hline
\end{tabular}


Tran, T. M. T., \& Yeh, A. (2020). Keeping it Real: Vietnamese-English Pragmatic Representations in EFL Textbook. International Journal of Language and Literary Studies, 2(1), 1-20.

Usó-Juan, E. (2007). The presentation and practice of the communicative act of requesting in textbooks: Focusing on modifiers. In: Alcón E, Safont MP (eds) Intercultural Language Use and Language Learning. Springer, Amsterdam, pp 223-243

Vellenga, H. (2004). Learning pragmatics from ESL \& EFL textbooks: How likely? TESL-EJ, 8(2), 2538.

Wong, J. (2002) "Applying” conversation analysis in applied linguistics: Evaluating dialogue in English as a second language textbooks. International Review of Applied Linguistics in Language Teaching, 40: 37-60.

Wyner, L., \& Cohen, A. D. (2015). Second language pragmatic ability: Individual differences according to environment. Studies in Second Language Learning and Teaching, 5(4), 519-556.

Ylldı-Ekin, M. T. \& Atak-Damar, E. (2013). Pragmatic awareness of EFL teacher trainees and their reflections on pragmatic practices. ELT Research Journal, 2.4, 176-190.

Yllmaz, D. \& Karatepe, Ç. (2013) Contextualisation in the primary classroom: A neglected issue in teacher education. In Strelova, O., Hiristov, I., Mortan, K. , Peeva, P., Sam, R., Sam, N., Galay, E. \& Atasoy, E. (2013) The Science and Education at the Beginning of the 21st Century in Turkey. Vol.3, pp.57-70, Sofia: St Klimenk Ohridski University Press.

Address

RumeliDE Journal of Language and Literature Studies

Osmanağa Mahallesi, Mürver Çiçeği Sokak, No:14/8

Kadıköy - ISTANBUL / TURKEY 34714

e-mail: editor@rumelide.com,

phone: +90 505 7958124, +90 2167730616 